\title{
MAPPING OF MINERAL PHASES AROUND DIAMONDS IN ECLOGITE XENOLITHS FROM THE UDACHNAYA KIMBERLITE PIPE (YAKUTIA): REMARKS TO THEIR METASOMATIC GENESIS
}

\author{
Spetsius Z.V. ${ }^{1}$ and Kamenetsky V.S. ${ }^{2}$ \\ ${ }^{1}$ Scientific Investigation Geology Enterprise, ALROSA Co Ltd, Mirny, Yakutia, 678170, Russia \\ ${ }^{2}$ Centre of Excellence in Ore Deposits, University of Tasmania, Hobart, Tasmania, 7001, Australia
}

\section{Introduction}

As show petrographic evidence overwhelming majority of diamonds in eclogite xenoliths are distributed between rockforming garnets $(\mathrm{Gt})$ and clinopyroxenes $(\mathrm{Cpx})$ in partial melting products. The crystallization products of partial melting include secondary $\mathrm{Cpx}$ (with low $\mathrm{Na}_{2} \mathrm{O}$ ), $\mathrm{Sp}$, $\mathrm{Pl}$, KFsp, and glass. Primary garnet also shows evidence for partial melting with typical development of kelyphitic rims. In intragranular partial-melt veins phlogopite $(\mathrm{Phl})$ and amphibole (Amph) also can be present. Such additional phases as carbonate, apatite, and sulfides are abundant in some xenoliths and fix the secondary assemblage around diamond crystals. Different associations of secondary minerals or stages of metasomatic processes and partial melting are possible to distinguish between diamond surrounding minerals (Spetsius and Griffin, 1999; Spetsius, and Taylor, 2002; Thomassot et al., 2008).

\section{Samples and Analytical techniques}

Major element compositions of $\mathrm{Gt}$ and $\mathrm{Cpx}$ in diamondiferous xenoliths as well secondary minerals and different phases of partial melt were analysed with a Superprobe JXA-8800R electron microprobe at ALROSA Co Ltd. We have done X-ray mapping of different phases surrounding diamonds in Udachnaya eclogites as well as elemental maps using high resolution new Cameca SX100 at the University of Tasmania. X-ray element maps (compositional patterns) for $\mathrm{Si}, \mathrm{Al}, \mathrm{Fe}, \mathrm{Ni}, \mathrm{Ca}, \mathrm{Mg}, \mathrm{Cr}, \mathrm{Na}$, $\mathrm{S}, \mathrm{K}$, and $\mathrm{P}$ were acquired for 10 samples of eclogite pieces and plates with diamonds or their imprints mounted individually in epoxy and exposed at the midplane parallel to the c-axis.

\section{Results}

In general, the distribution of elements and their relationships are very complex, but consideration of the distribution of Fe, Ni. K and $\mathrm{S}$ have permitted three main groups of compositional patterns to be identified. These groups could belong to three different associations of secondary minerals or stages of metasomatic processes and partial melting that is possible to distinguish between diamond surrounding minerals. Such example of different clinopyroxene phases is shown in diamondiferous eclogite xenolith from the Udachnaya pipe (Fig. 1). All 10 crystals presenting on a polished plate are sitting in the secondary clinopyroxene with spongy texture or surrounded by the new phase of Cpx-2 from the next stage of partial melting (Table 1). Besides, there is present Cpx-3 that is really different in composition with high (>10 wt. \%) sodium content and elongated shape.

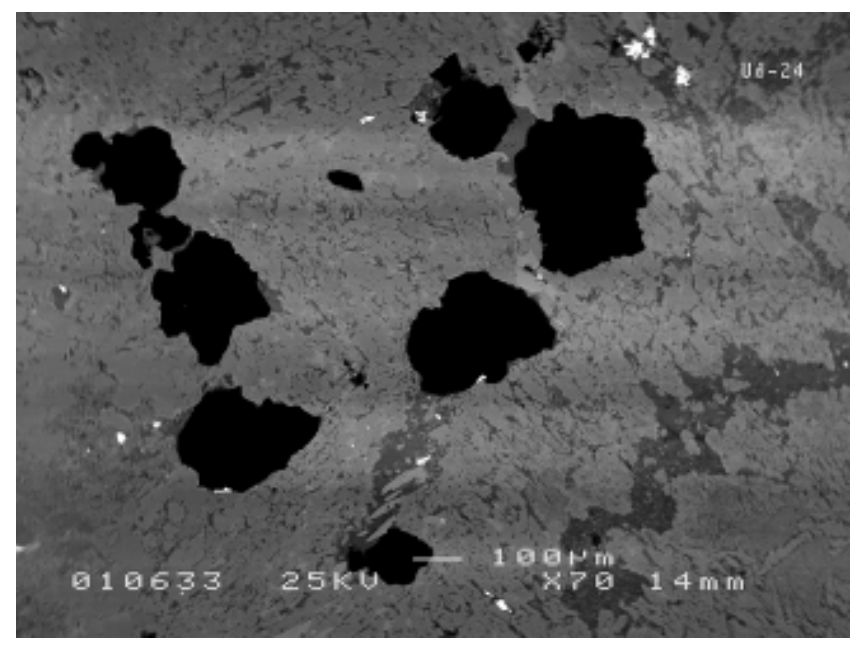

Fig.1. Plate with diamonds (black) in secondary clinopyroxenes of eclogite xenolith from the Udachnaya pipe. Sample Ud-24, $\mathrm{BSE}+\mathrm{Cl}$. Size of diamonds vary from 50 to 300 microns. At the bottom are obvious three elongated needles of high sodium clinopyroxene-3. Clinopyroxenes analyses are given in Table 1. 


\section{$10^{\text {th }}$ International Kimberlite Conference, Bangalore - 2012}

\section{Table-1 Compositions of relict and metasomatic clinopyroxenes in eclogite xenolith (sample Ud-24).}

\begin{tabular}{|c|c|c|c|c|}
\hline Description & $\begin{array}{l}\text { Cpx } \\
\text { relict }\end{array}$ & $\begin{array}{l}\text { Cpx1 } \\
\text { spongy }\end{array}$ & $\begin{array}{l}\text { Cpx2 } \\
\text { prt-ml. }\end{array}$ & $\begin{array}{l}\text { Cpx3 prt } \\
\text { needle }\end{array}$ \\
\hline $\mathrm{SiO}_{2}$ & 56.58 & 53.16 & 54.51 & $\mathbf{5 3 . 6 4}$ \\
\hline $\mathrm{TiO}_{2}$ & 0.44 & 0.39 & 0.31 & 1.2 \\
\hline $\mathrm{Al}_{2} \mathrm{O}_{3}$ & 11.11 & 4.07 & 4.82 & 0.1 \\
\hline $\mathrm{FeO}$ & 5.13 & 6.88 & 5.88 & 21.5 \\
\hline MgO & 8.58 & 14.67 & 14.25 & 4.56 \\
\hline $\mathrm{CaO}$ & 12.22 & 19.95 & 18.26 & 6.6 \\
\hline $\mathrm{Na}_{2} \mathrm{O}$ & 6.62 & 1.72 & 2.55 & 10.6 \\
\hline Oxide total & 100.68 & 100.84 & 100.58 & 98. \\
\hline
\end{tabular}

Obtained results confirm that in all cases diamond crystals have contacted with different secondary phases such as clinopyroxenes of partial melting products, phlogopites, carbonates and sulfides (Fig. 2).

Three different associations of secondary minerals or stages of metasomatic processes and partial melting are possible to distinguish between diamond surrounding minerals (Spetsius and Griffin, 1999; Spetsius, and Taylor, 2002). At first stage is fixed partial melting of primary clinopyroxene and replacement of omphacite by less sodium pyroxene with a spongy texture (Cpx1, Table-1). Second stage of partial melting is displayed in growth a little higher aluminous pyroxene (Cpx2, Table-1), spinel, phlogopite, plagioclase, and sometimes amphibole. In some cases between these phases is present a high sodium pyroxene $\left(\mathrm{Na}_{2} \mathrm{O} \approx 10\right.$ wt. \%, Fig. 1$)$, but in comparison with primary omphacite this pyroxene contain less $\mathrm{Al}$ and $\mathrm{Ca}$ and high content of Fe. Such additional phases as carbonate, apatite, sulfide and others are abundant in some xenoliths; they look as a late stage of alteration and sometimes probably are connected with the interaction of protokimberlite fluids.

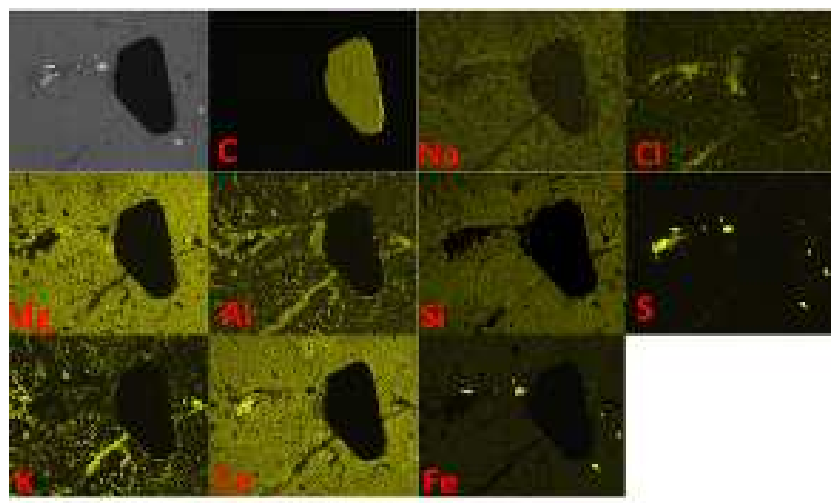

Fig. 2. X-ray element map sample UG31 showing contact with diamond that is surrounded by partial melted clinopyroxene, sulfides and other secondary phases as chloraluminite $\mathrm{AlCl} 3 \cdot 6(\mathrm{H} 2 \mathrm{O})$ are present.
Sulfides and volatile rich minerals are widely distributed between partial melting products surrounded diamonds (Fig. 3) as was shown by Spetsius and Taylor $(2002,2008)$.

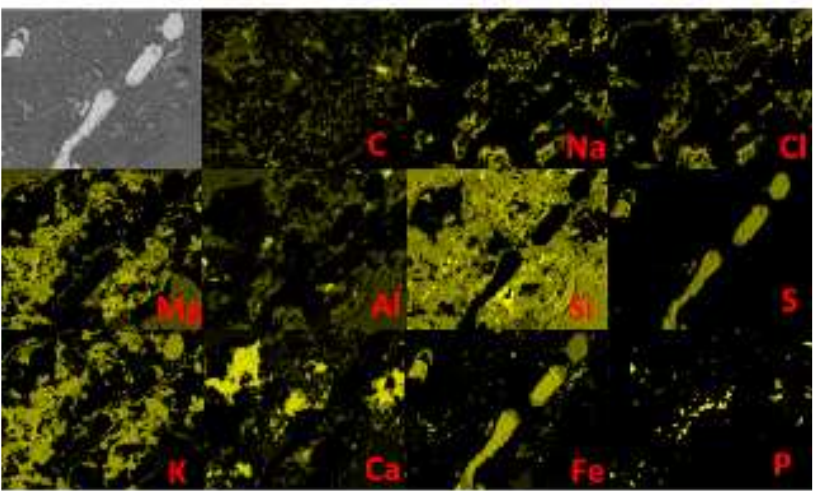

Fig. 3. X-ray element map sample UG-26. Pyrrhotitedjerfisherite veins and secondary phases of phlogopite, calcite and apatite are obvious.

Remarkable data have been taken during investigation of the diamondiferous eclogite xenolith with high content of sulfides in the rock (sample UE-12, Fig.4). In the whole it was recovered 540 crystals and diamond chips from this sample (about 300 crystals with the size $>1 \mathrm{~mm}$ ). This unique bimineral eclogite xenolith consists of high magnesian garnet - 43\%, omphacite clinopyroxene - 55\% and sulfides $-2 \%$. It should be noticed that garnet has zonal composition with variation in $\mathrm{MgO}$ (17.31-19.60), $\mathrm{FeO}$ (10.97-12.45), $\mathrm{CaO}$ (15.85-16.35) wt. \% with the increasing in $\mathrm{Mg}, \mathrm{Cr}$ and $\mathrm{Ti}$ and decreasing in $\mathrm{Fe}$ and $\mathrm{Ca}$ from the core to rim.

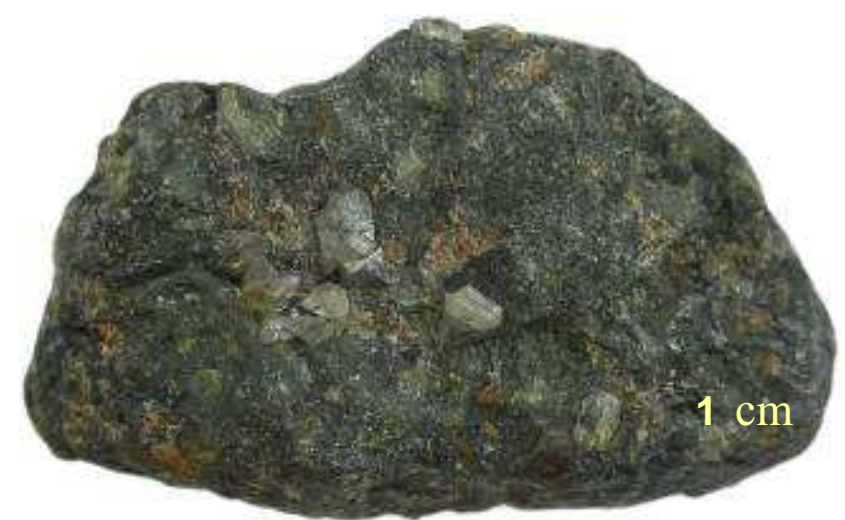

Fig. 4. Diamondiferous xenolith from the Udachnaya pipe. Sample UE-12 containing octahedron crystals different in size.

Sample contains abundant sulfides (Fig.5). From the X-ray maps and microprobe analyses it is obvious that sulfides are presented by pyrrothite with blocks of pentlandite or chalcopyrite that are surrounded by the djerfisherite $(\mathrm{Dj})$ 


\section{$10^{\text {th }}$ International Kimberlite Conference, Bangalore - 2012}

rims (Fig. 6). Djerfisherites rims have varied contents of $\mathrm{K}$, $\mathrm{Cl}$ and $\mathrm{S}$ (Table-2).

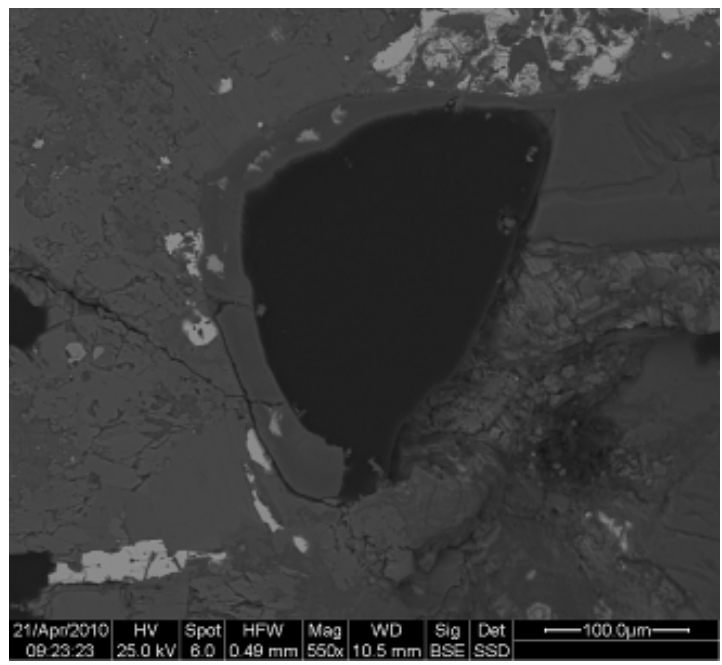

Fig. 5. Diamond in xenolith (sample UE-12) that is surrounded by vein of secondary clinopyroxene with dispersed sulfides.

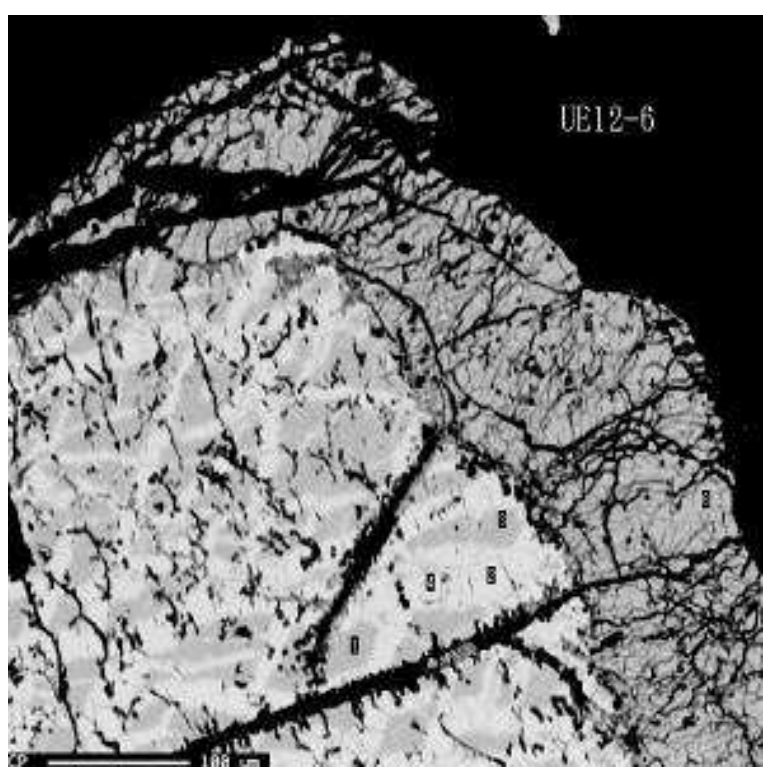

Fig. 6. Pyrrhotite-chalcopyrite sulfide nodule with the djerfisherite rim in diamondiferous xenolith from the Udachnaya pipe. Sample UE-12.

Mapping of sulfide grains shows that they are complicated in composition and consist of pyrrothite with chalcopyrite blebs or exsolution of pentlandite. In most cases they are surrounded by the djerfisherite rims. Djerfisherites have varied compositions even in the separate grains (see Table 2) that is displayed on Fig. 7.
Table-2 Compositions of sulfide minerals in eclogite xenolith (sample UE-12).

\begin{tabular}{|l|l|l|l|l|l|l|}
\hline $\begin{array}{l}\text { Sf- } \\
\text { phase }\end{array}$ & Po & Chp & Po & Chp & Dj & Dj \\
\hline$\#$ & 1 & 2 & 3 & 4 & 5 & 6 \\
\hline $\mathrm{S}$ & 35.73 & 35.22 & 36.09 & 35.42 & 33.02 & 32.31 \\
\hline $\mathrm{Cu}$ & 0.08 & 34.05 & 0.10 & 34.11 & 12.01 & 15.02 \\
\hline $\mathrm{Fe}$ & 62.26 & 31.02 & 62.70 & 30.94 & 38.78 & 36.15 \\
\hline $\mathrm{K}$ & 0.03 & 0.01 & 0.00 & 0.01 & 8.31 & 8.15 \\
\hline $\mathrm{Ni}$ & 0.04 & 0.25 & 0.01 & 0.21 & 5.12 & 4.50 \\
\hline $\mathrm{Zn}$ & 0.15 & 0.00 & 0.06 & 0.00 & 0.00 & 0.00 \\
\hline $\mathrm{Cl}$ & 0.02 & 0.00 & 0.03 & 0.01 & 1.02 & 0.97 \\
\hline $\mathrm{Co}$ & 0.11 & 0.04 & 0.10 & 0.03 & 0.14 & 0.09 \\
\hline Total & 98.41 & 100.59 & 99.09 & 100.73 & 98.38 & 97.18 \\
\hline
\end{tabular}

Numbers corresponds to the points of analyses on Fig. 6.

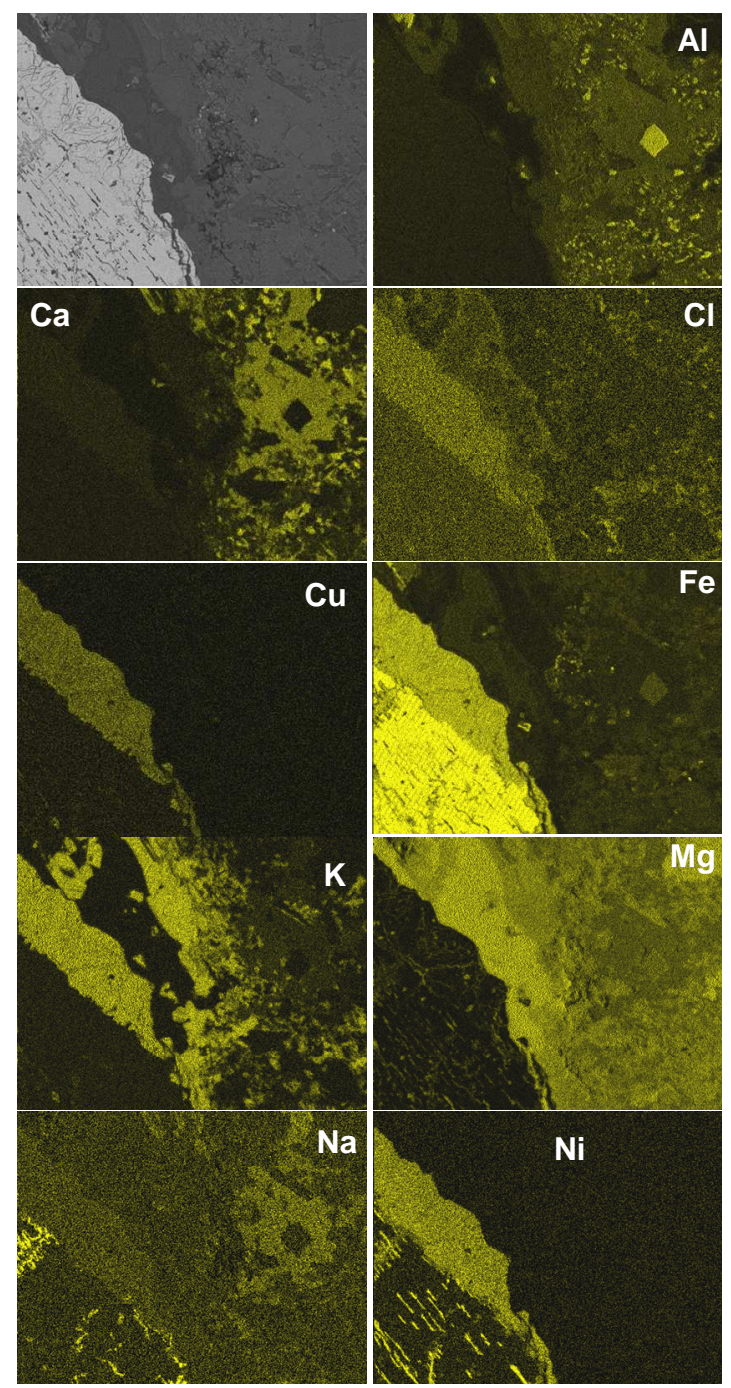




\section{$10^{\text {th }}$ International Kimberlite Conference, Bangalore - 2012}

Fig. 7. X-ray element map of pyrrhotite sulfide with the djerfisherite rim in the contact with partial-melt products in diamondiferous xenolith from the Udachnaya pipe. Sample UE-12.

As was shown earlier sulfides probably played an important role in formation of diamonds (Bulanova et al., 1990; Spetsius, Bulanova, 1993; Chepurov et al., 1997). We shoud stress that variations in compositions of djerfisherites probably reflects the changing in passing fluids on the last stages of diamond growth because as was shown (Spetsius, et al., 1987) this mineral is connecting with the mantle metasomatose and its presence confirm the important role of potassium and others volatile components in the process of metasomatose and fluctuating conditions in time of these events.

All these evidences allowed suggesting about the presence of metasomatic fluids with the varied composition that probably are responsible for the growths of diamonds.

\section{Discussion}

Obtained results allowed concluding that melting zones at clinopyroxene-garnet interface: association of low-Na, Al high-Ca clinopyroxene (sodalite), carbonates, sulphates, apatite, phlogopite, amphibole and djerfisherite in xenoliths appears to be a product of direct precipitation from the passing metasomatic fluid infiltrating into lithospheric xenoliths or reactions of evolved kimberlitic fluids/melts with primary minerals in eclogite xenoliths. In result constraints on the degree of partial melting in different eclogites have been done and incipient melting in eclogite xenoliths was confirmed. In consideration of the presence of phlogopite, amphibole and others volatile minerals we can state that diamonds were formed in high volatile environment most probable through metasomatic process. Sulfide components should be taken in consideration when we reconstruct a possible model of diamonds formation in mantle rocks especially in the case of their growth on one of the stage of partial melting and connected metasomatic events.

\section{Conclusion}

The main findings of the mapping of mineral phases around diamonds in eclogite xenoliths from the Udachnaya kimberlite pipe are:

- X-ray element mapping could be a useful and powerful method for the studying and understanding of processes of metasomatose and partial melting in eclogites.

-There is an obvious connection between the growth of part of diamonds in xenoliths, especially microdiamonds and metasomatically induced partial melting. The growth of these second generation diamonds probably occurred under reduced P-T conditions. This crystallization has occurred from a sulfide-silicate fluid-rich melt or fluid. Petrographic and mineralogical observations strongly suggest that diamonds grow on different stages of metasomatose and partial melting.

-Fluids play an important role in initiating of partial melting of eclogites and metasomatic growth of diamonds.

\section{References}

Bulanova, G.P., Spetsius, Z.V., and Leskova, N.V. (1990) Sulfides in diamonds and xenoliths from kimberlite pipes of Yakutia. Novosibirsk: Nauka, 117 p. (in Russian).

Chepurov, A.I., Fedorov, I.I., and Sonin, V.M. (1997) Experimental modelling of the diamond formation processes. Novosibirsk: Siberian Branch RAS, 197 p. (in Russian).

Spetsius, Z.V. (1999) Two generation of diamonds in the eclogite xenoliths. In: Gurney, J.J., Gurney, J.L., Pascoe, M.D. and Richardson, S.H., eds. Proceedings Volume of 7th International Kimberlite Conference, 2. Cape Town: Red Roof Design, pp. 823-828.

Spetsius, Z.V., and Bulanova, G. P. (1993) The role of sulfide melts in genesis of natural diamonds. I-st symp. Brasiliero de Geologia do Diamante. Cuiaba-Brazil., p. 53-55.

Spetsius, Z.V., Bulanova, G.P., and Leskova, N.V. (1987) Djerfisherite and his genesis in the kimberlitic rocks. Doklady Akademy Nauk SSSR, v. 293, N 1, pp.199-202 (in Russian).

Spetsius, Z V., and Griffin, B. J. (1998) Secondary phases around diamonds in eclogites from Udachnaya pipe: application to the genesis. Ext. Abstr. of 8th International Kimberlite Conference, Cape Town, pp. 850-852.

Spetsius, Z.V. and Taylor, L.A. (2002) Partial melting in mantle eclogite xenoliths: connection with diamond genesis. International Geology Review, v. 44, pp. 973-987.

Spetsius, Z.V., Taylor, L.A. (2008) Diamonds of Siberia: Photographic evidence for their origin. Tranquility Base Press, Lenoir City, Tennessee, USA, 278p.

Thomassot, E. Cartigny, P. Harris, J.W. (2008) Metasomatic Processes in the Cratonic Lithosphere: the case of Polycrystalline Diamonds. Ext. Abstr. of 9th International Kimberlite Conference, Frankfurt. 